\title{
Effects of Different Parts on the Chemical Composition, Silage Fermentation Profile, In Vitro and In Situ Digestibility of Paper Mulberry
}

\author{
Yangyi Hao (D), Shuai Huang, Gaokun Liu, Jun Zhang (D), Gang Liu, Zhijun Cao (D), Yajing Wang, Wei Wang \\ and Shengli $\mathrm{Li}^{*}$
}

check for

updates

Citation: Hao, Y.; Huang, S.; Liu, G.; Zhang, J.; Liu, G.; Cao, Z.; Wang, Y.; Wang, W.; Li, S. Effects of Different Parts on the Chemical Composition, Silage Fermentation Profile, In Vitro and In Situ Digestibility of Paper Mulberry. Animals 2021, 11, 413. https://doi.org/10.3390/ani11020413

Academic Editors: Manuel Fondevila and Mariangela Caroprese

Received: 29 December 2020

Accepted: 30 January 2021

Published: 5 February 2021

Publisher's Note: MDPI stays neutral with regard to jurisdictional claims in published maps and institutional affiliations.

Copyright: (C) 2021 by the authors Licensee MDPI, Basel, Switzerland. This article is an open access article distributed under the terms and conditions of the Creative Commons Attribution (CC BY) license (https:// creativecommons.org/licenses/by/ $4.0 /)$.
State Key Laboratory of Animal Nutrition, Beijing Engineering Technology Research Center of Raw Milk Quality and Safety Control, College of Animal Science and Technology, China Agricultural University, Beijing 100193, China; haoyangyi0928@163.com (Y.H.); huangshuai510@126.com (S.H.); liugk339@163.com (G.L.); june_zh16@cau.edu.cn (J.Z.); liugang_0402@126.com (G.L.); caozhijun@cau.edu.cn (Z.C.);

yajingwang@cau.edu.cn (Y.W.); wei.wang@cau.edu.cn (W.W.)

* Correspondence: lisheng0677@163.com; Tel.: +86-010-62731254

Simple Summary: Paper mulberry (Broussonetia papyrifera, PM) is a potential roughage source widely distributed in Asia, but the chemical composition, silage fermentation, and digestibility are not fully understood. Here, we compared the chemical composition, silage fermentation, and digestibility of leaf, stem, and whole plant of PM to evaluate its feeding value. The result showed that the leaf had lower fiber content and higher protein content than the stem and whole plant. Meanwhile, the stem silage had the lowest $\mathrm{pH}$ value and lactate content, while those in the leaf were the highest. The in vitro and in situ digestibility showed the leaf was more digestible. Our study gives the reference of different parts of PM to be used as a feedstuff.

Abstract: Paper mulberry (Broussonetia papyrifera, PM) is high protein but unutilized as a feed source. The study explores the different parts (leaf, stem, and whole plant) of PM chemical composition, silage fermentation, and in vitro and in situ digestibility, aiming to give some guidelines to PM usage as feed. The result showed that the leaf had a higher fresh weight than the stem $(p<0.05)$. The dry matter contents of the three groups had no differences. The highest crude protein, ether extract, water-soluble carbohydrate, ash, calcium, phosphorus, amino acid contents, and butter capacity were observed in the leaf $(p<0.05)$. The stem had the highest $(p<0.05)$ neutral detergent fiber, acid detergent fiber, and lignin contents. After ensiling, the stem silage had the lowest $\mathrm{pH}$ value, ammonia nitrate $\left(\mathrm{NH}_{3}-\mathrm{N}\right)$, lactate, acetate, and propionate $(p<0.05)$. The leaf silage had the highest $\mathrm{pH}$ value $(p<0.05)$. The lactate, acetate, and propionate in the leaf and whole plant silage had no difference. The butyrate was not detected in all silage. The in vitro and in situ digestibility experiments showed the leaf had the highest digestibility $(p<0.05)$, which could produce more volatile fatty acids and have a higher effective digestibility. These results allow a greater understanding of PM to be used as a feedstuff.

Keywords: paper mulberry; nutritional value; silage; digestibility

\section{Introduction}

The shortage of feed resources and high feeding costs have become important factors restricting the development of the dairy farming industry. Exploitation of new feed resources may be an effective solution for this dilemma. Paper mulberry (Broussonetia papyrifera, PM) is a dioecious plant native to mainland Southeast Asia and East Asia [1]. Owing to its strong rooting ability and rapid growth, PM is considered a plant capable of providing environmental protection in many areas [2]. As one of China's top ten targeted poverty alleviation projects, China has planted over 300,000 hectares of PM, which serves as a 
potential animal feed source with economic and functional merits. The bark of PM is a good source of fiber for the production of paper. The mulberry fruit contains many bioactive chemical compounds, such as alkaloids, flavonoids, anthocyanins, and some polyphenols, strengthening animals' immunity and antioxidant capacity [3]. It was reported that the extracts of mulberry could ameliorate inflammation in rats [4], and the anthocyanins from mulberry fruits can scavenge free radicals and inhibit low-density lipid oxidation [5]. Owing to its high protein concentration in the leaf, PM can also be used as a feedstuff for animals [6]. A previous study found that dietary supplementation with mulberry leaf powder can improve digestion in ruminants [7]. Diets with $10 \%$ or $15 \%$ whole plant PM silage, which is substituted for alfalfa hay, could reportedly reduce the milk somatic cell count and enhance the antioxidant capacity and immune function of lactating dairy cows, but also decreased the feed intake [8].

A good feedstuff should be conveniently conserved and utilized. Currently, silage is the best conserving technique because it is affordable and easy to make, which also has the advantage of minimum loss of nutrients. However, to our knowledge, no information is available on the PM chemical composition and silage fermentation profile. The reports of PM progressing, conserving, and using are also lacking. All these limit PM being used as a feedstuff. To understand PM fully, we compared the leaf, stem, and whole plant nutrition of PM. Therefore, the study's objective was to explore the effects of different parts on the chemical composition, silage fermentation profile, and in vitro and in situ digestibility of PM.

\section{Materials and Methods}

\subsection{Harvesting and Different Fractions of the Plants}

The PM was planted in Henan province, which is in central China. The area's longitude and latitude are $114.82^{\circ}$ and $34.82^{\circ}$, respectively, which belong to a monsoon climate of medium latitudes with an average annual temperature of $15.7^{\circ} \mathrm{C}$ and an average yearly rainfall of $485 \mathrm{~mm}$ in the last three years. The field was sandy loam and weeds were previously growing there. A total of $70 \mathrm{~kg} / \mathrm{ha} \mathrm{N}$ fertilizer was applied annually in the field. The PM was seeded using transplant seedlings, which can be harvested continuously for about fifteen years and can harvest three to five times a year. The PM was harvested from three fields at a $1.2 \mathrm{~m}$ growth height and a cutting height of $0.2 \mathrm{~m}$ in May 2018. First, twenty plants were collected in each field and weighted. We separated twelve plants into leaf and stem and weighted, respectively. The remaining plants served as the whole plant. Each field plant is one replicate, and we have three replicates in all.

\subsection{Nutritional Composition of Fresh Samples}

The PM was treated as described by Gallo et al. [9]. Briefly, the samples were immediately placed into a forced-draft oven (DGG-9240B; Shanghai-ShenXin Inc., Shanghai, China) at $65^{\circ} \mathrm{C}$ for $48 \mathrm{~h}$ to determine dry matter (DM). Samples were then milled through a $1 \mathrm{~mm}$ screen using a rotating-feedstuff mill (KRT-34; KunJie, Beijing, China) and stored at ambient temperature before subsequent analysis. The neutral detergent fiber (NDF) and acid detergent fiber (ADF) were determined using an ANKOM fiber analyzer (A2000i; American ANKOM, NY, USA), as described by Van Soest et al. [10]. The lignin was measured with reference to Theander et al. [11]. Nitrogen was measured according to method 984.13 of the Association of Official Analytical Chemists (AOAC) [12]. Crude protein (CP) was calculated by multiplying 6.25 by the nitrogen content. Water-soluble carbohydrate (WSC) was measured using the anthrone method described by Murphy et al. [13]. Ash (method 924.05) and ether extract (EE, method 920.39) were measured according to the methods of the AOAC [12]. The buffering capacity of PM was measured according to the sodium hydroxide titration method [14]. The amino acid composition of PM was measured using high-performance liquid chromatography (HPLC) (Agilent 1200, Agilent Technologies, Everett, WA, USA) as previously described by Li et al. [15]. 


\subsection{PM Silage \\ 2.3.1. Silage Making}

After harvesting, separation, and weighing, the leaf, stem, and whole plant PM from three different fields were cut into 1-2 cm using a manual forage chopper (93ZT-300; Xingrong Co., Ltd. Guangzhou, China), respectively. The cut pieces were then packed into plastic polyethylene bottles ( $0.5 \mathrm{~L}$ capacity). Air was removed from the bottles, which were then sealed using a vacuum sealer. All silage samples had a density higher than $800 \mathrm{~kg} / \mathrm{m}^{3}$ and were stored at ambient temperature for 45 days.

\subsubsection{Silage Chemical Composition Determination}

In each bottle, $20 \mathrm{~g}$ of silage was blended with $180 \mathrm{~mL}$ deionized water and stored at $4{ }^{\circ} \mathrm{C}$ for $24 \mathrm{~h} \mathrm{[16]}$. The mixture was then filtered through four layers of cheesecloth to determine the fermentation parameters. The silage's $\mathrm{pH}$ was measured immediately using a pH electrode after the filtering (Model pH B-4; Shanghai Chemical, Shanghai, China). The $\mathrm{NH}_{3}-\mathrm{N}$ concentration was measured using the phenol-sodium hypochlorite colorimetry method described by Broderick et al. [17]. The organic acid content was measured using HPLC (Agilent 1200, Agilent Technologies, Everett, WA, USA), according to Yuan et al. [18]. The remaining sample was used for nutritional value detection. The pretreatment, DM, $\mathrm{NDF}, \mathrm{ADF}, \mathrm{Ash}, \mathrm{CP}$, and EE detection methods were the same as those described in the fresh PM chemical composition detection.

\subsection{In Vitro Digestibility}

The leaf, stem, and whole plant PM silage were taken for in vitro digestibility experiment. The in vitro gas production was determined using an Automated Trace Gas Recording System (AGRS) for microbial fermentation, as described by Bai et al. [19,20]. Briefly, $500 \mathrm{mg}$ (DM basis) of representative samples (four replicates) of each treatment group were weighed into $120 \mathrm{~mL}$ glass bottles, and $50 \mathrm{~mL}$ of a freshly prepared buffer solution was added to each bottle [20]. The components of the buffer solution are presented in Table S1. Rumen fluid was collected from three fistulated Holstein dairy cows before morning feeding, stored in a vacuum flask, and immediately taken to the lab. All cows were in a state of peak lactation, and the formula of the diets is presented in Table S2. Before usage, rumen fluid was filtered through four-layer cheesecloth and mixed. A volume of $25 \mathrm{~mL}$ of filtered rumen fluid was added into the $120 \mathrm{~mL}$ glass bottles. The bottles were then purged with anaerobic $\mathrm{N}_{2}$ for $5 \mathrm{~s}$, sealed with a butyl rubber stopper, and individually connected with medical plastic infusion pipes to the gas inlets of the AGRS to record cumulative gas production continuously. The measurement of $\mathrm{pH}$ and $\mathrm{NH}_{3}-\mathrm{N}$ was the same as described in the silage fermentation test. The in vitro dry matter digestibility (IVDMD) was calculated using differential subtraction according to the dry matter content of substrates before and after in vitro incubation. Volatile fatty acids (VFA) were determined using HPLC (Agilent 1200, Agilent Technologies, Everett, WA, USA) [21].

\subsection{In Situ Digestibility}

The in situ DM, CP, NDF, and ADF degradation rates of the leaf, stem, and whole plant silage were determined by reference to Nocek et al. [22]. The dried samples were milled through a 3-mm sieve, and $5 \mathrm{~g}$ of the prepared sample was weighed and placed in nylon bags ( 45 -mm pore size, $8 \times 16 \mathrm{~cm}$ bag size) in six repetitions. These samples were incubated for 4, 8, 12, 24,30,36, 48, and $72 \mathrm{~h}$ in the rumen of three fistulated cows (each cow had two repetitions). The cows and diet were the same as those in the in vitro experiment.

After removing the bags at each time point, the bags were washed in running tap water until the outlet water became clear. Bags were then dried to a constant weight at $65^{\circ} \mathrm{C}$ for $48 \mathrm{~h}$ and weighed. The residues were ground through a $1 \mathrm{~mm}$ sieve for further analysis. The $\mathrm{DM}, \mathrm{CP}, \mathrm{NDF}$, and $\mathrm{ADF}$ were measured as described before. 


\subsection{Calculation and Statistical Analysis}

2.6.1. Calculation of Gas Production Parameters for In Vitro Fermentation

The cumulative gas production $\left(G P_{48}\right)(\mathrm{mL} / \mathrm{g})$ data were recorded using the AGRS system and fitted to the Groot model as Equation (1) [23]:

$$
G P_{t}=A /\left[1+\left(\frac{C}{t}\right)^{B}\right]
$$

$A$ is the asymptotic gas production $(\mathrm{mL} / \mathrm{g}) ; B$ is a sharpness parameter determining the curve's shape; $C$ is the time (h) at which half of $A$ is reached; and $t$ is in vitro incubation time (h).

The time at which maximum rate of substrate degradation is reached (TRmaxS, h), the maximum rate of substrate digestion (RmaxS, h), the time at which RmaxG is reached $(T R \max G, \mathrm{~h})$, and the maximum gas production rate $(R \max G, \mathrm{~mL} / \mathrm{h})$ were calculated with $A, B$, and $C$ as Equation (2)-(5) [24]:

$$
\begin{aligned}
& \operatorname{TRmax} S=C \times(B-1)^{(1 / B)} \\
& \operatorname{Rmax} S=\left[B \times \operatorname{TRmax}^{(B-1)}\right] /\left(C^{B}+\operatorname{TRmaxs}^{B}\right) \\
& T R \max G=C \times[(B-1) /(B+1)]^{(1 / B)} \\
& \operatorname{Rmax} G=\left[A \times C^{B} \times B \times T R \max G^{(-B-1)}\right] /\left[1+C^{B} \times \operatorname{TRmax} G^{(-B)}\right]^{2}
\end{aligned}
$$

2.6.2. Calculation of in Situ Digestibility

The degradation data were fitted to the following exponential equation [25]:

$$
y=a+b\left(1-e^{-c t}\right)
$$

$y$ is the nutrient disappearance rate in the rumen at time $t ; a$ is the rapidly degradable fraction; $b$ is the potentially degradable fraction; and $c$ is the constant rate of degradation of $b(\% / h)$.

The effective degradability (ED) of nutrients was calculated by applying the following equation [25]:

$$
E D=a+\left(\frac{b c}{c+k}\right)
$$

$a, b$, and $c$ are the same parameters represented in Equation (6), and $k$ is the rumen outflow rate. The $E D$ of nutrients was calculated using an outflow rate of $0.07 / \mathrm{h}$, according to the report of Batajoo and Shaver [26].

\subsubsection{Statistical Analysis}

Analyses were performed using SAS (SAS version 9.4, SAS Institute Inc., Cary, NC, USA). All data were subjected to one-way analysis of variance (ANOVA). The statistical model was as follows:

$$
Y_{i j}=\mu+T_{i}+E_{i j}
$$

$Y_{i j}$ represents the observed dependent variables; $\mu$ is the overall mean; $T_{i}$ is the effect of treatment; and $E_{i j}$ is the residual error. Statistical differences between means were determined using Duncan's multiple comparison test. Differences were considered significant when the $p$-value was less than 0.05 .

\section{Results}

\subsection{Yield and Chemical Composition}

The leaf had a higher fresh weight (FW) yield than the stem $(p<0.05)$ (Table 1), and the leaf:stem ratio was 1.45:1. The leaf had the highest $(p<0.05) \mathrm{CP}, \mathrm{EE}, \mathrm{WSC}$, ash, calcium, 
phosphorus, and buffer capacity, and the lowest $(p<0.05)$ NDF, ADF, and lignin. The highest $(p<0.05) \mathrm{NDF}, \mathrm{ADF}$, and lignin and the lowest $(p<0.05) \mathrm{CP}$, WSC, ash, calcium concentration, and buffer capacity was observed in the stem. The different parts of PM did not affect $(p>0.05)$ DM.

Table 1. Fresh weight yield and chemical composition of different parts of paper mulberry.

\begin{tabular}{cccc}
\hline \multirow{2}{*}{ Items $^{1}$} & \multicolumn{3}{c}{ Groups } \\
\cline { 2 - 4 } & Leaf & Stem & Whole Plant \\
\hline FW yield (kg/per plant) & $1.70 \pm 0.05^{\mathrm{b}}$ & $1.17 \pm 0.04^{\mathrm{c}}$ & $2.79 \pm 0.09^{\mathrm{a}}$ \\
DM (g/kg) & $261.05 \pm 4.00$ & $271.06 \pm 8.06$ & $266 \pm 6.07$ \\
CP (g/kg DM) & $241.24 \pm 0.98^{\mathrm{a}}$ & $84.93 \pm 3.29^{\mathrm{c}}$ & $169.40 \pm 4.23^{\mathrm{b}}$ \\
NDF (g/kg DM) & $447.09 \pm 31.61^{\mathrm{c}}$ & $680.63 \pm 14.60^{\mathrm{a}}$ & $502.79 \pm 11.07^{\mathrm{b}}$ \\
ADF (g/kg DM) & $239.00 \pm 13.86^{\mathrm{c}}$ & $565.91 \pm 9.81^{\mathrm{a}}$ & $348.88 \pm 5.57^{\mathrm{b}}$ \\
Lignin (g/kg DM) & $33.45 \pm 5.79^{\mathrm{c}}$ & $75.67 \pm 2.12^{\mathrm{a}}$ & $59.61 \pm 3.11^{\mathrm{b}}$ \\
EE (g/kg DM) & $29.24 \pm 0.04^{\mathrm{a}}$ & $22.82 \pm 0.25^{\mathrm{b}}$ & $22.54 \pm 2.88^{\mathrm{b}}$ \\
WSC (g/kg DM) & $45.82 \pm 4.62^{\mathrm{a}}$ & $11.57 \pm 0.77^{\mathrm{c}}$ & $33.24 \pm 1.32^{\mathrm{b}}$ \\
Ash (g/kg DM) & $116.62 \pm 0.73^{\mathrm{a}}$ & $47.31 \pm 0.41^{\mathrm{c}}$ & $84.95 \pm 5.38^{\mathrm{b}}$ \\
Calcium (g/kg DM) & $26.47 \pm 1.79^{\mathrm{a}}$ & $9.09 \pm 1.07^{\mathrm{c}}$ & $15.55 \pm 0.92^{\mathrm{b}}$ \\
Phosphorus (g/kg DM) & $3.01 \pm 0.11^{\mathrm{a}}$ & $2.50 \pm 0.23^{\mathrm{b}}$ & $2.26 \pm 0.28^{\mathrm{b}}$ \\
Buffer capacity (mE/Kg DM) & $418.30 \pm 21.25^{\mathrm{a}}$ & $187.97 \pm 5.51^{\mathrm{c}}$ & $297.94 \pm 26.86^{\mathrm{b}}$ \\
\hline
\end{tabular}

Values with different lowercase superscript letters ( $\mathrm{a}, \mathrm{b}$, and $\mathrm{c}$ ) are significantly different $(p<0.05)$ between different parts. ${ }^{1}$ FW: fresh weight; DM: dry matter; CP: crude protein; NDF: neutral detergent fiber; ADF: acid detergent fiber; WSC: water-soluble carbohydrate; EE: ether extract.

The stem and leaf had the lowest $(p<0.05)$ and highest $(p<0.05)$ detected amino acid, respectively (Table 2). Notably, the lysine and methionine in the leaf were 13.5 and $3.9 \mathrm{~g} / \mathrm{kg}$, respectively, with a ratio approximating 3:1. The top five amino acids in the leaf, stem, and whole plant were aspartic acid, glutamic acid, leucine, proline, and lysine. The bottom five amino acids were cysteine, tryptophan, methionine, histidine, and tyrosine.

Table 2. Amino acid composition of different parts of the paper mulberry.

\begin{tabular}{cccc}
\hline & \multicolumn{3}{c}{ Groups } \\
\cline { 2 - 4 } Items & Leaf & Stem & Whole Plant \\
\cline { 2 - 4 } Animo acid (g/kg DM) & & & \\
Tryptophan & $3.74 \pm 0.04^{\mathrm{a}}$ & $0.83 \pm 0.04^{\mathrm{c}}$ & $2.41 \pm 0.02^{\mathrm{b}}$ \\
Cysteine & $2.21 \pm 0.05^{\mathrm{a}}$ & $0.51 \pm 0.02^{\mathrm{c}}$ & $1.63 \pm 0.07^{\mathrm{b}}$ \\
Methionine & $3.92 \pm 0.15^{\mathrm{a}}$ & $1.04 \pm 0.04^{\mathrm{c}}$ & $2.53 \pm 0.23^{\mathrm{b}}$ \\
Aspartic acid & $23.42 \pm 0.71^{\mathrm{a}}$ & $9.83 \pm 0.20^{\mathrm{c}}$ & $17.81 \pm 0.43^{\mathrm{b}}$ \\
Threonine & $11.12 \pm 0.12^{\mathrm{a}}$ & $2.74 \pm 0.05^{\mathrm{c}}$ & $7.23 \pm 0.11^{\mathrm{b}}$ \\
Serine & $9.73 \pm 0.23^{\mathrm{a}}$ & $2.84 \pm 0.05^{\mathrm{c}}$ & $6.89 \pm 0.17^{\mathrm{b}}$ \\
Glutamic acid & $24.68 \pm 0.28^{\mathrm{a}}$ & $6.33 \pm 0.10^{\mathrm{c}}$ & $16.53 \pm 0.49^{\mathrm{b}}$ \\
Proline & $15.72 \pm 0.37^{\mathrm{a}}$ & $5.30 \pm 0.17^{\mathrm{c}}$ & $10.63 \pm 0.62^{\mathrm{b}}$ \\
Glycine & $11.32 \pm 0.18^{\mathrm{a}}$ & $2.58 \pm 0.07^{\mathrm{c}}$ & $7.59 \pm 0.20^{\mathrm{b}}$ \\
Alanine & $10.29 \pm 0.20^{\mathrm{a}}$ & $2.54 \pm 0.04^{\mathrm{c}}$ & $7.04 \pm 0.18^{\mathrm{b}}$ \\
Valine & $13.41 \pm 0.38^{\mathrm{a}}$ & $3.46 \pm 0.04^{\mathrm{c}}$ & $9.03 \pm 0.23^{\mathrm{b}}$ \\
Isoleucine & $10.40 \pm 0.21^{\mathrm{a}}$ & $2.45 \pm 0.11^{\mathrm{c}}$ & $7.03 \pm 0.18^{\mathrm{b}}$ \\
Leucine & $18.82 \pm 0.22^{\mathrm{a}}$ & $4.21 \pm 0.15^{\mathrm{c}}$ & $12.52 \pm 0.24^{\mathrm{b}}$ \\
Tyrosine & $7.48 \pm 0.18^{\mathrm{a}}$ & $0.91 \pm 0.02^{\mathrm{c}}$ & $4.47 \pm 0.17^{\mathrm{b}}$ \\
Phenylalanine & $11.67 \pm 0.32^{\mathrm{a}}$ & $2.58 \pm 0.10^{\mathrm{c}}$ & $7.66 \pm 0.08^{\mathrm{b}}$ \\
Histidine & $4.51 \pm 0.08^{\mathrm{a}}$ & $1.26 \pm 0.03^{\mathrm{c}}$ & $3.17 \pm 0.12^{\mathrm{b}}$ \\
Lysine & $13.53 \pm 0.28^{\mathrm{a}}$ & $3.48 \pm 0.10^{\mathrm{c}}$ & $9.68 \pm 0.24^{\mathrm{b}}$ \\
Arginine & $12.81 \pm 0.22^{\mathrm{a}}$ & $2.43 \pm 0.04^{\mathrm{c}}$ & $8.27 \pm 0.10^{\mathrm{b}}$ \\
\hline
\end{tabular}

Values with different superscript letters $(\mathrm{a}, \mathrm{b}$, and $\mathrm{c})$ are significantly different $(p<0.05)$ between the different parts.

\subsection{Silage Fermentation Profile}

The $\mathrm{CP}$ and $\mathrm{pH}$ were the highest $(p<0.05)$ and the NDF and ADF were the lowest $(p<0.05)$ in the leaf silage (Table 3$)$. The $\mathrm{CP}, \mathrm{pH}$, and acetate in the stem silage were 
significantly lower $(p<0.05)$ than leaf silage and whole plant silage, while NDF and ADF were significantly higher $(p<0.05)$ than the other groups. The $\mathrm{pH}, \mathrm{NH}_{3}-\mathrm{N}$, lactate, acetate, propionate and butyrate in whole plant PM silage were $4.80,43.94(\mathrm{~g} / \mathrm{kg} \mathrm{TN}), 90.65,22.71$, 23.96 , and $0(\mathrm{~g} / \mathrm{kg} \mathrm{DM})$. There is no significant difference of $\mathrm{NH}_{3}-\mathrm{N}$, lactate, and propionate between leaf silage and whole plant silage, but they were significantly higher $(p<0.05)$ than the stem silage. The butyrate was too low to be detected in all silage samples. The stem silage also did not have propionate be detected.

Table 3. Chemical composition and fermentation profile of different parts of paper mulberry silage.

\begin{tabular}{|c|c|c|c|}
\hline \multirow{2}{*}{ Items ${ }^{1}$} & \multicolumn{3}{|c|}{ Groups } \\
\hline & Leaf & Stem & Whole Plant \\
\hline \multicolumn{4}{|l|}{ Chemical Composition } \\
\hline $\mathrm{DM}(\mathrm{g} / \mathrm{kg})$ & $261.04 \pm 4.00 \mathrm{ab}$ & $271.06 \pm 8.06^{\mathrm{a}}$ & $256.80 \pm 1.70^{b}$ \\
\hline $\mathrm{CP}(\mathrm{g} / \mathrm{kg} \mathrm{DM})$ & $252.87 \pm 11.57^{\mathrm{a}}$ & $92.28 \pm 1.90^{\mathrm{c}}$ & $190.76 \pm 6.26^{b}$ \\
\hline NDF (g/kg DM) & $304.25 \pm 6.06^{c}$ & $670.19 \pm 2.68^{a}$ & $415.45 \pm 12.91^{b}$ \\
\hline $\mathrm{ADF}(\mathrm{g} / \mathrm{kg} \mathrm{DM})$ & $158.48 \pm 14.29^{c}$ & $580.47 \pm 8.57^{\mathrm{a}}$ & $323.72 \pm 23.90^{b}$ \\
\hline \multicolumn{4}{|l|}{ Fermentation Profile } \\
\hline $\mathrm{pH}$ & $5.09 \pm 0.06^{\mathrm{a}}$ & $3.81 \pm 0.01^{\mathrm{c}}$ & $4.80 \pm 0.20^{b}$ \\
\hline $\mathrm{NH}_{3}-\mathrm{N}(\mathrm{g} / \mathrm{kg} \mathrm{TN})$ & $44.07 \pm 7.37^{\mathrm{a}}$ & $20.91 \pm 3.23^{b}$ & $43.94 \pm 10.87^{\mathrm{a}}$ \\
\hline Lactate (g/kg DM) & $99.77 \pm 2.29^{a}$ & $52.07 \pm 6.62^{b}$ & $90.65 \pm 13.92^{\mathrm{a}}$ \\
\hline Acetate (g/kg DM) & $39.63 \pm 4.71^{\mathrm{a}}$ & $6.43 \pm 1.78^{\mathrm{c}}$ & $22.71 \pm 2.52^{b}$ \\
\hline Propionate (g/kg DM) & $21.03 \pm 2.27^{\mathrm{a}}$ & $\mathrm{ND}^{\mathrm{b}}$ & $23.96 \pm 6.03^{a}$ \\
\hline Butyrate (g/kg DM) & ND & ND & ND \\
\hline
\end{tabular}

Values with different lowercase superscript letters $(\mathrm{a}, \mathrm{b}$, and $\mathrm{c})$ are significantly different $(p<0.05)$ between different parts. ${ }^{1} \mathrm{DM}$ : dry matter; $\mathrm{CP}$ : crude protein; NDF: neutral detergent fiber; ADF: acid detergent fiber; $\mathrm{TN}$ : total $\mathrm{N}, \mathrm{NH}_{3}-\mathrm{N} / \mathrm{TN}$ : $\mathrm{NH}_{3}-\mathrm{N}$ to total $\mathrm{N}$ ratio; $\mathrm{ND}$ : no detection.

\subsection{In Vitro Digestibility}

The leaf silage had the highest IVDMD, while the stem silage was the lowest $(p<0.05)$ (Table 4). The IVDMD of the whole plant PM silage was $683.51(\mathrm{~g} / \mathrm{kg} \mathrm{DM})$. Acetate concentration was significantly lower $(p<0.05)$ in the stem silage than the leaf and whole plant silage. Compared to the stem and whole plant silage, the leaf silage had a higher $(p<0.05)$ propionate content. Total VFA in the leaf silage was significantly higher $(p<0.05)$ than the stem silage. There was no distinction $(p>0.05)$ of $\mathrm{pH}$ and $\mathrm{NH}_{3}-\mathrm{N}$ within the three groups.

The $\mathrm{GP}_{48}$, the time $(\mathrm{h})$ at which half of asymptotic gas production is reached (parameters $C)$, RmaxG, TRmaxS, RmaxS, and TRmaxG had no significant distinction ( $p>0.05)$ within the three different silage. The asymptotic gas production $(\mathrm{mL} / \mathrm{g})($ parameter $A)$ and sharpness parameter determining the shape of the curve (parameter $B$ ) in the leaf silage were higher $(p<0.05)$ than other silage.

\subsection{In Situ Digestibility}

The degradation rate was the highest in leaf silage and lowest in stem silage $(p<0.05)$ (Figure 1). The EDs of DM, CP, NDF, and ADF in the leaf silage were the highest, and those of the stem silage were the lowest $(p<0.05)$ (Table 5). The EDs of DM, CP, NDF, and ADF in leaf, stem, and whole plant PM silage were 621.96, 208.92, and 439.59; 612.85, 191.74, and $455.05 ; 526.38,244.92$, and $412.93 ; 500.23,280.17$, and 381.29; respectively. The rapid degradation fraction (parameter $a$ ) of DM and $\mathrm{CP}$ in the leaf silage was highest $(p<0.05)$, while that of ADF showed no significant difference $(p>0.05)$ within the different parts. The leaf silage showed the highest $(p<0.05)$ potential degradation fraction (parameter $b$ ) of NDF and ADF. Potential degradation fractions of DM, CP, and ADF in the stem group were lower $(p<0.05)$ than those in the other two groups. In contrast, the potential degradation fractions of NDF in the stem group showed no significant difference $(p>0.05)$ from the whole plant group. The $\mathrm{CP}$ and NDF constant rate of slow degradation fraction (parameter $c$ ) were the highest $(p<0.05)$ in the leaf silage, while that of DM in the whole plant and leaf silage was higher $(p<0.05)$ than the stem silage. 
Table 4. The IVDMD, in vitro gas production kinetics, and rumen fluid fermentation profile of different parts of paper mulberry silage.

\begin{tabular}{|c|c|c|c|}
\hline \multirow{2}{*}{ Items ${ }^{1}$} & \multicolumn{3}{|c|}{ Groups } \\
\hline & Leaf & Stem & Whole Plant \\
\hline IVDMD (g/kg DM) & $909.00 \pm 22.73^{a}$ & $484.31 \pm 22.16^{c}$ & $683.51 \pm 8.6^{b}$ \\
\hline $\mathrm{pH}$ & $6.94 \pm 0.02$ & $6.93 \pm 0.07$ & $6.97 \pm 0.05$ \\
\hline $\mathrm{NH}_{3}-\mathrm{N}(\mathrm{mg} / \mathrm{dL})$ & $12.08 \pm 0.45$ & $11.10 \pm 0.83$ & $11.94 \pm 0.30$ \\
\hline Acetate $(\mathrm{mmol} / \mathrm{L})$ & $53.03 \pm 0.59^{a}$ & $48.25 \pm 1.79^{b}$ & $52.99 \pm 1.59^{\mathrm{a}}$ \\
\hline Propionate (mmol/L) & $24.67 \pm 1.04^{\mathrm{a}}$ & $19.09 \pm 0.98^{b}$ & $20.07 \pm 0.87^{b}$ \\
\hline Isobutyrate (mmol/L) & $0.72 \pm 0.17^{b}$ & $1.57 \pm 0.08^{\mathrm{a}}$ & $1.67 \pm 0.15^{\mathrm{a}}$ \\
\hline Butyrate $(\mathrm{mmol} / \mathrm{L})$ & $9.76 \pm 0.76$ & $8.32 \pm 0.39$ & $9.28 \pm 0.52$ \\
\hline Isovalerate $(\mathrm{mmol} / \mathrm{L})$ & $2.39 \pm 0.28$ & $2.04 \pm 0.15$ & $2.44 \pm 0.21$ \\
\hline Valerate $(\mathrm{mmol} / \mathrm{L})$ & $2.05 \pm 0.07^{\mathrm{a}}$ & $1.65 \pm 0.01^{b}$ & $1.92 \pm 0.10^{a b}$ \\
\hline Total VFA (mmol/L) & $92.63 \pm 2.83^{a}$ & $80.92 \pm 1.36^{b}$ & $88.37 \pm 1.89^{a b}$ \\
\hline $\mathrm{GP}_{48}(\mathrm{~mL} / \mathrm{g})$ & $90.05 \pm 7.74$ & $74.24 \pm 12.28$ & $82.40 \pm 8.31$ \\
\hline$A$ & $95.65 \pm 7.72^{\mathrm{a}}$ & $75.92 \pm 12.53^{b}$ & $89.56 \pm 8.50^{b}$ \\
\hline$B$ & $1.44 \pm 0.10^{\mathrm{a}}$ & $1.28 \pm 0.04^{b}$ & $1.27 \pm 0.05^{b}$ \\
\hline C & $3.95 \pm 0.33$ & $4.00 \pm 0.57$ & $4.09 \pm 0.60$ \\
\hline TRmaxG & $1.21 \pm 0.31$ & $0.78 \pm 0.09$ & $0.78 \pm 0.25$ \\
\hline RmaxG & $15.05 \pm 2.10$ & $12.28 \pm 1.95$ & $13.38 \pm 2.60$ \\
\hline TRmaxS & $2.07 \pm 0.54$ & $1.56 \pm 0.02$ & $1.60 \pm 0.48$ \\
\hline RmaxS & $0.20 \pm 0.02$ & $0.19 \pm 0.03$ & $0.19 \pm 0.03$ \\
\hline
\end{tabular}

Values with different lowercase superscript letters $(\mathrm{a}, \mathrm{b}$, and $\mathrm{c})$ are significantly different $(p<0.05)$ between different parts. ${ }^{1}$ IVDMD: in vitro dry matter digestibility; VFA: volatile fatty acid; $\mathrm{GP}_{48}$ : the cumulative gas production at $48 \mathrm{~h}$; $A$ : the asymptotic gas production $(\mathrm{mL} / \mathrm{g}) ; B$ : a sharpness parameter determining the shape of the curve; $C$ : the time (h) at which half of $A$ is reached and $t$ is in vitro incubation time; TRmaxS: the time at which maximum rate of substrate degradation is reached (h); RmaxS: the maximum rate of substrate digestion $(/ \mathrm{h})$; TRmaxG: the time at which RmaxG is reached (h); RmaxG: the maximum gas production rate (mL/h).

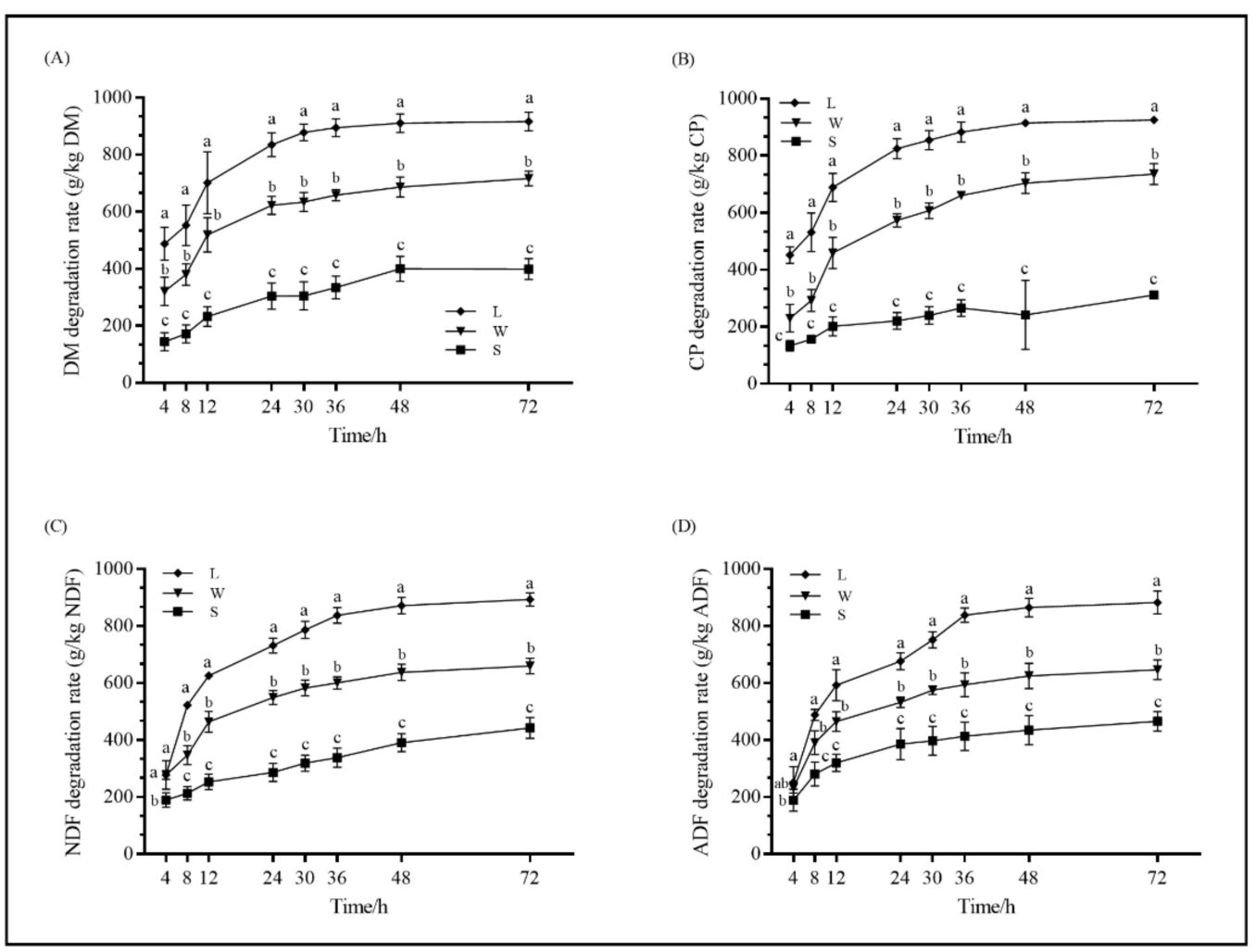

Figure 1. The real-time degradation rates of different parts of PM silage in rumen (A), DM, (B) CP, (C) NDF, and (D) ADF. Means within the same time point with different letters are significantly different $(p<0.05)$. L: leaf; S: stem; W: whole plant; DM: dry matter; CP: crude protein; NDF: neutral detergent fiber; ADF: acid detergent fiber. 
Table 5. Parameters of DM, CP, NDF, and ADF dynamic degradation model of different parts of paper mulberry silage.

\begin{tabular}{|c|c|c|c|}
\hline \multirow{2}{*}{ Items ${ }^{1}$} & \multicolumn{3}{|c|}{ Groups } \\
\hline & Leaf & Stem & Whole Plant \\
\hline \multicolumn{4}{|l|}{ DM } \\
\hline$a(\mathrm{~g} / \mathrm{kg} \mathrm{DM})$ & $337.91 \pm 65.14^{a}$ & $104.96 \pm 7.63^{b}$ & $147.74 \pm 39.18^{b}$ \\
\hline$b(\mathrm{~g} / \mathrm{kg} \mathrm{DM})$ & $601.13 \pm 43.94^{\mathrm{a}}$ & $345.70 \pm 37.62^{b}$ & $544.90 \pm 29.24^{a}$ \\
\hline$c(\mathrm{~g} / \mathrm{kg} \mathrm{DM})$ & $63.09 \pm 11.86^{\mathrm{a}}$ & $30.71 \pm 4.63^{b}$ & $78.72 \pm 4.98^{\mathrm{a}}$ \\
\hline$a+b(\mathrm{~g} / \mathrm{kg} \mathrm{DM})$ & $939.04 \pm 23.73^{a}$ & $450.66 \pm 34.85^{c}$ & $702.64 \pm 15.41^{b}$ \\
\hline ED (g/kg DM) & $621.96 \pm 19.15^{a}$ & $208.92 \pm 6.12^{c}$ & $439.59 \pm 27.43^{b}$ \\
\hline \multicolumn{4}{|l|}{$\mathrm{CP}$} \\
\hline$a(\mathrm{~g} / \mathrm{kg} \mathrm{DM})$ & $306.21 \pm 41.64^{\mathrm{a}}$ & $155.68 \pm 16.15^{b}$ & $174.71 \pm 5.73^{b}$ \\
\hline$b(\mathrm{~g} / \mathrm{kg} \mathrm{DM})$ & $626.80 \pm 32.98^{a}$ & $293.78 \pm 99.84^{b}$ & $629.84 \pm 29.96^{a}$ \\
\hline$c(\mathrm{~g} / \mathrm{kg} \mathrm{DM})$ & $89.14 \pm 1.97^{a}$ & $50.47 \pm 7.34^{b}$ & $59.41 \pm 17.28^{b}$ \\
\hline$a+b(\mathrm{~g} / \mathrm{kg} \mathrm{DM})$ & $933.01 \pm 15.72^{a}$ & $409.45 \pm 116.09^{b}$ & $804.56 \pm 30.77^{a}$ \\
\hline ED (g/kg DM) & $612.85 \pm 23.25^{a}$ & $191.74 \pm 10.65^{c}$ & $455.05 \pm 42.93^{b}$ \\
\hline \multicolumn{4}{|l|}{ NDF } \\
\hline$a(\mathrm{~g} / \mathrm{kg} \mathrm{DM})$ & $87.82 \pm 15.49^{\mathrm{c}}$ & $162.08 \pm 15.59^{b}$ & $214.19 \pm 23.66^{a}$ \\
\hline$b(\mathrm{~g} / \mathrm{kg} \mathrm{DM})$ & $788.51 \pm 11.68^{a}$ & $414.21 \pm 11.61^{b}$ & $458.06 \pm 23.19^{b}$ \\
\hline$c(\mathrm{~g} / \mathrm{kg} \mathrm{DM})$ & $87.76 \pm 4.07^{\mathrm{a}}$ & $20.56 \pm 8.61^{\mathrm{c}}$ & $54.43 \pm 7.84^{\mathrm{b}}$ \\
\hline$a+b(\mathrm{~g} / \mathrm{kg} \mathrm{DM})$ & $876.33 \pm 7.00^{\mathrm{a}}$ & $576.29 \pm 124.42^{b}$ & $672.25 \pm 44.54^{b}$ \\
\hline ED (g/kg DM) & $526.38 \pm 3.03^{\mathrm{a}}$ & $244.92 \pm 10.83^{c}$ & $412.93 \pm 18.68^{b}$ \\
\hline \multicolumn{4}{|l|}{ ADF } \\
\hline$a(\mathrm{~g} / \mathrm{kg} \mathrm{DM})$ & $134.26 \pm 4.39$ & $137.02 \pm 22.41$ & $102.44 \pm 18.32$ \\
\hline$b(\mathrm{~g} / \mathrm{kg} \mathrm{DM})$ & $736.82 \pm 35.47^{a}$ & $315.26 \pm 49.50^{c}$ & $524.71 \pm 12.98^{b}$ \\
\hline$c(\mathrm{~g} / \mathrm{kg} \mathrm{DM})$ & $69.08 \pm 5.28$ & $58.41 \pm 17.13$ & $79.41 \pm 2.79$ \\
\hline$a+b(\mathrm{~g} / \mathrm{kg} \mathrm{DM})$ & $871.09 \pm 14.80^{a}$ & $452.27 \pm 29.12^{c}$ & $627.15 \pm 10.90^{b}$ \\
\hline ED (g/kg DM) & $500.23 \pm 14.13^{a}$ & $280.17 \pm 20.50^{\mathrm{c}}$ & $381.29 \pm 14.32^{b}$ \\
\hline
\end{tabular}

Values with different lowercase superscript letters $(\mathrm{a}, \mathrm{b}$, and $\mathrm{c})$ are significantly different $(p<0.05)$ between different parts. ${ }^{1} a$ : the rapid degradation fraction; $b$ : the slow degradation fraction; $c$ : the constant rate of degradation of $b(\% / h)$; ED: effective degradability; DM: dry matter; CP: crude protein; NDF: neutral detergent fiber; ADF: acid detergent fiber.

\section{Discussion}

\subsection{Yield and Chemical Composition}

Previous studies found that forage chemical composition could influence the animal feeding behavior, feed intake, metabolism, and performance [27-29]. Fiber is beneficial for rumination and rumen $\mathrm{pH}$; simultaneously, it is negatively correlated with dry matter intake and digestibility [30]. Leaf has less undigestible fiber, which tends to be a widely used roughage source for ruminants [29,30]. Lignin is a complex, phenolic polymer found in plant cell walls essential for mechanical support, water, and mineral transport [31]. Stem, as the support of the whole plant, is lignified during the growth of the plant. Therefore, the higher lignin that was observed in the stem and whole plant in the current study was understandable. With the lower fiber and higher $\mathrm{CP}$, the leaf had a higher nutritional value; it could be recommended to feed the high-lactation dairy cows, while the stem or the whole plant could be provided to the heifers or dry cows. Silage is a great conserving technique for PM. WSC is beneficial for silage making, while the buffer capacity goes against it $[32,33]$. The higher WSC in leaf was more advantageous for silage making than stem, while the buffer capacity index was contrary in the two parts. Ash is an important factor affecting feed buffer capacity [34]. We speculated that the PM is a broad-leaved plant, and the leaf surface is relatively coarse, which adheres some dust from the air and causes its ash content to be high. The high ash content enhanced the leaf buffer capacity. Based on the high buffer capacity in leaf and low WSC in stem, it is necessary to consider their respective limiting factors when making PM silage. 
Balanced amino acid composition of the diet could improve animal production and performance [35]. The first and second limiting amino acids are lysine and methionine for dairy cows, respectively [35,36]. Leaf had the highest amino acid content, and the ratio of lysine:methionine in PM leaf was close to 3:1, which is approximately an ideal protein ratio for the dairy cows [35]. Some studies indicated histidine is another limiting amino acid in lactating dairy cows based on corn silage and alfalfa haylage (the most common diet type in China) [37-39]. However, compared to other amino acids, the PM's histidine content (including leaf, stem, and whole plant) was relatively low, which should be taken into consideration when a PM-based diet is supplemented with concentrates for dairy cows. Among the top five amino acids in the leaf and whole plant, leucine and lysine were the essential amino acids for dairy cows, making up for the deficiency that cows cannot synthesize these amino acids by themselves [40,41]. In short, PM's amino acid composition does not entirely meet the ideal amino acid requirements of dairy cows. When using PM to make formulas, it needs to combine with the high histidine and methionine feeds to achieve amino acid balance.

\subsection{Silage Fermentation Profile}

High buffer capacity could inhibit the silage $\mathrm{pH}$ downregulation [32]. The highest $\mathrm{pH}$ value of leaf silage could be attributed to the higher buffer capacity in the leaf. Buffer capacity became the dominant factor in downregulating the $\mathrm{PM}$ silage $\mathrm{pH}$ values, which offset the leaf's WSC effects. Si et al. showed that feeding dairy cows PM silage with a $\mathrm{pH}$ value of 5.06 did not affect the milk yield performance and body condition score [8], which indicated the PM silage in our study qualified for the feeding of dairy cows. Our results $\mathrm{NH}_{3}-\mathrm{N}$ content was similar to legume silage but higher than grass silage [32]. $\mathrm{NH}_{3}-\mathrm{N}$ was the by-product of silage fermentation, and it was produced by protease, accompanied by the decomposition of proteins by microorganisms $[42,43]$. The leaf and whole plant silage had a higher $\mathrm{NH}_{3}-\mathrm{N}$ content; this may be due to its higher $\mathrm{CP}$ content.

Lactate, produced via homofermentative, could downregulate the silage $\mathrm{pH}$ values and inhibit harmful bacteria's growth [32]. Acetate could enhance the stability of silage by inhibiting the second fermentation [32,33]. The higher organic acid content in the leaf and whole plant is a sign of good quality silage, which is beneficial for dairy cows' production performance [28,33]. However, the discrepancy between the organic acid and $\mathrm{pH}$ values in leaf silage may be due to its higher WSC and buffer capacity. There seems to be other unidentified chemical components in PM that conserve it under these conditions, and this should further explore it. Butyrate is ordinarily undetectable in well-fermented silage [44]. The current study testified that PM could be processed into a successful silage with no butyrate being detected. However, to produce better-fermentation (lower $\mathrm{pH}, \mathrm{NH}_{3}-\mathrm{N}$ contents, etc.) PM silage, it is better to add some organic acid (like acetate) and molasses to the leaf and stem, respectively [32,33].

\subsection{Digestibility}

The digestibility is affected by feed species, chemical composition, animal DM intake, healthy status, rumen bacteria, etc. $[22,45,46]$. Our previous studies have shown that adding $4.5-18.0 \%$ PM silage (substituting the alfalfa and oat grass) to the diet did not affect the total-tract apparent digestibility of dairy cows [47]. However, in this study, we proved that the different parts of PM had distinct digestibility. The high diet NDF level could decrease the ruminal digestibility [30]. Stem had more fiber, and leaf had higher $\mathrm{CP}$; these different chemical composition influence PM's digestibility performance. The leaf had the highest IVDMD and in situ digestibility, mainly attributed to its lower fiber content $[46,48,49]$. The digestibility kinetics is affected by feed particle size, species, and composition [22,50]. Under the same test procedure (particle size, species, etc.), the leaf group had a higher and faster degradation rate proven by the higher theoretical maximum gas production and in site dynamic degradation parameters [46,48]. All these results indicate that the leaf silage was more digestible $[48,51,52]$. 
The digested organic matter was fermented to VFA and gas production (GP) or converted to microbial protein [48]. The total GP is an indicator of forage digestibility [53]. In agreement with Getachew et al. [54], the leaf's lower lignin content contributed to the higher GP. Fermentative gas is mainly produced when feedstuffs are fermented to acetate and butyrate [55]. There is a positive correlation between VFA production and GP [56]. The IVDMD and VFA results were in correspondence with GP in the current in vitro experiment. The higher IVDMD contributed to the higher total VFA content of the leaf, which could provide a more digestible substance to fermentation. The acetate and propionate acid are the primary energy source of ruminants; they are the precursor of milk fat and milk lactose, respectively [27]. Thus the in vitro experiment indicated leaf might be more beneficial for animal production.

\section{Conclusions}

As a new roughage feedstuff, the different parts of paper mulberry had distinct chemical compositions. The leaf was more nutritious and digestible. Considering the low water-soluble carbohydrate and high buffer capacity, adding some additives to enhance the paper mulberry silage fermentation quality is necessary. Mechanically separating the leaf from the stem before mixing with the diet is recommended to improve paper mulberry's utilization efficiency. Further study is needed to elucidate the effects of different paper mulberry parts on animals' production performance.

Supplementary Materials: The following are available online at https:/ /www.mdpi.com/2076-261 5/11/2/413/s1, Table S1: The components of the buffer solution for in vitro experiments, Table S2: Ingredient and chemical composition of the basal diet fed fistulated cows during the in vitro experiment (DM basis).

Author Contributions: Conceptualization, S.L., Z.C., Y.W., and W.W.; methodology, Y.H. and Y.W.; software, G.L. (Gang Liu); validation, W.W., S.H., and J.Z.; formal analysis, Y.H.; investigation, Z.C. and G.L. (Gaokun Liu); resources, W.W.; data curation, Y.H.; writing —original draft preparation, Y.H.; writing - review and editing, S.H. and W.W.; visualized supervision, S.H.; project administration, Y.H.; funding acquisition, S.L. All authors have read and agreed to the published version of the manuscript.

Funding: The present study was funded by the China Agriculture Research System (CARS-36).

Institutional Review Board Statement: The in vitro and in situ experimental procedures were approved by the Ethical Committee of the College of Animal Science and Technology of China Agriculture University (Protocol number: 2013-5-LZ).

Data Availability Statement: The data presented in this study are available on request from the corresponding author. The data are not publicly available due to restrictions by the research group.

Acknowledgments: We thank CARS-36 for their financial support and the Zhong Ke Hua Gou company (Lankao, Henan, China) for the use of their paper mulberry.

Conflicts of Interest: The authors declare no conflict of interest.

\section{References}

1. Penailillo, J.; Olivares, G.; Moncada, X.; Payacan, C.; Chang, C.S.; Chung, K.F.; Matthews, P.J.; Seelenfreund, A.; Seelenfreund, D. Sex Distribution of Paper Mulberry (Broussonetia papyrifera) in the Pacific. PLoS ONE 2016, 11, e0161148. [CrossRef]

2. Xianjun, P.; Yucheng, W.; Ruiping, H.; Meiling, Z.; Shihua, S. Global transcriptomics identification and analysis of transcriptional factors in different tissues of the paper mulberry. BMC Plant Biol. 2014, 14, 194. [CrossRef]

3. Zhang, H.; Ma, Z.F.; Luo, X.; Li, X. Effects of mulberry fruit (Morus alba L.) consumption on health outcomes: A mini-review. Antioxidants 2018, 7, 69. [CrossRef] [PubMed]

4. Kim, A.J.; Park, S. Mulberry extract supplements ameliorate the inflammation-related hematological parameters in carrageenaninduced arthritic rats. J. Med. Food. 2006, 9, 431-435. [CrossRef]

5. Du, Q.; Zheng, J.; Xu, Y. Composition of anthocyanins in mulberry and their antioxidant activity. J. Food Compost. Anal. 2008, 21, 390-395. [CrossRef]

6. Tang, F.; Chen, N.; Zhao, M.; Wang, Y.; He, R.; Peng, X.; Shen, S. Identification and functional divergence analysis of WOX gene family in paper mulberry. Int. J. Mol. Sci. 2017, 18, 1782. [CrossRef] 
7. Ouyang, J.; Wang, M.; Hou, Q.; Feng, D.; Pi, Y.; Zhao, W. Effects of dietary mulberry leaf powder in concentrate on the rumen fermentation and ruminal epithelium in fattening Hu sheep. Animals 2019, 9, 218. [CrossRef]

8. Si, B.; Tao, H.; Zhang, X.; Guo, J.; Cui, K.; Tu, Y.; Diao, Q. Effect of Broussonetia papyrifera L. (paper mulberry) silage on dry matter intake, milk composition, antioxidant capacity and milk fatty acid profile in dairy cows. Asian-Australas J. Anim. Sci. 2018, 31, 1259-1266. [CrossRef] [PubMed]

9. Gallo, A.; Giuberti, G.; Bruschi, S.; Fortunati, P.; Masoero, F. Use of principal factor analysis to generate a corn silage fermentative quality index to rank well- or poorly preserved forages. J. Sci. Food Agric. 2016, 96, 1686-1696. [CrossRef] [PubMed]

10. Van Soest, P.J.; Lewis, B.A. Methods for dietary fiber, neutral detergent fiber, and nonstarch polysaccharides in relation to animal nutrition. J. Dairy Sci. 1991, 74, 3583-3597. [CrossRef]

11. Olof, T.; Åman, P.; Eric, W.; Roger, A.; Dan, P. Total dietary fiber determined as neutral sugar residues, uronic acid residues, and Klason lignin (the Uppsala method): Collaborative study. J. AOAC Int. 1995, 78, 1030-1044. [CrossRef]

12. AOAC. Official Methods of Analysis, 15th ed.; Association of Official Analytical Chemists: Arlington, VA, USA, 1990.

13. Murphy, R.P. A method for the extraction of plant samples and the determination of total soluble carbohydrates. J. Sci. Food Agric. 1958, 9, 714-717. [CrossRef]

14. Playne, M.J.; Mcdonald, P. Buffering constituents of herbage and of silage. J. Sci. Food Agric. 1966, 17, 264-268. [CrossRef]

15. Li, R.; Hou, G.; Jiang, X.; Song, Z.; Fan, Z.; Hou, D.X.; He, X. Different dietary protein sources in low protein diets regulate colonic microbiota and barrier function in a piglet model. Food Funct. 2019, 10, 6417-6428. [CrossRef] [PubMed]

16. Tao, Y.; Sun, Q.; Li, F.; Xu, C.; Cai, Y. Comparative analysis of ensiling characteristics and protein degradation of alfalfa silage prepared with corn or sweet sorghum in semiarid region of Inner Mongolia. Anim. Sci. J. 2020, 91, e13321. [CrossRef] [PubMed]

17. Broderick, G.F.; Kang, J.H.; Kang, J.H. Automated simultaneous determination of ammonia and total amino acids in ruminal fluid and in vitro media. J. Dairy Sci. 1980, 63, 46-75. [CrossRef]

18. Yuan, X.J.; Wen, A.Y.; Wang, J.; Desta, S.T.; Dong, Z.H.; Shao, T. Effects of four short-chain fatty acids or salts on fermentation characteristics and aerobic stability of alfalfa (Medicago sativa L.) silage. J. Sci. Food Agric. 2018, 98, 328-335. [CrossRef] [PubMed]

19. Bai, S.; Cao, Z.J.; Cao, B.B.; Yang, H.J.; Li, S.L.; Liu, J.X. Effects of different forage combinations in total mixed rations on in vitro gas production kinetics, ruminal and milk fatty acid profiles of lactating cows. Anim. Sci. J. 2018, 89, 1261-1270. [CrossRef] [PubMed]

20. Menke, K.H.; Stengass, H. Estimation of the energetic feed value obtained from chemical analysis and in vitro gas production using rumen fluid. Anim. Res. Dev. 1988, 28, 7-55.

21. Ryan, J.P. Determination of volatile fatty acids and some related compounds in ovine rumen fluid, urine, and blood plasma, by gas-liquid chromatography. Anal. Biochem. 1980, 108, 374-384. [CrossRef]

22. Nocek, J.E. In situ and other methods to estimate ruminal protein and energy digestibility: A review. J. Dairy Sci. 1988, 91, 2051-2069. [CrossRef]

23. Groot, J.C.J.; Cone, J.W.W.; Illiams, B.A.; Debersaques, F.M.A.; Lantinga, E.A. Multiphasic analysis of gas production kinetics for in vitro fermentation of ruminant feeds. Anim. Feed Sci. Technol. 1996, 64, 77-89. [CrossRef]

24. Yang, H.J.; Tamminga, S.; Williams, B.A.; Dijkstra, J.; Boer, H. In vitro gas and volatile fatty acids production profiles of barley and maize and their soluble and washout fractions after feed processing. Anim. Feed Sci. Technol. 2005, 120, 125-140. [CrossRef]

25. Orskov, E.R.; Mcdonald, I. Estimation of protein degradability in the rumen from incubation measurements weighted according to rate of passage. J. Agric. Sci. 1979, 92, 499-503. [CrossRef]

26. Batajoo, K.K.; Shaver, R.D. Impact of nonfiber carbohydrate on intake, digestion, and milk production by dairy cows. J. Dairy Sci. 1994, 77, 1580-1588. [CrossRef]

27. Hall, M.B.; Mertens, D.R. A 100-year review: Carbohydrates-characterization, digestion, and utilization. J. Dairy Sci. 2017, 100, 10078-10093. [CrossRef]

28. Grant, R.J.; Ferraretto, L.F. Silage review: Silage feeding management: Silage characteristics and dairy cow feeding behavior. J. Dairy Sci. 2018, 101, 4111-4121. [CrossRef]

29. Kanjanapruthipong, J.; Junlapho, W.; Karnjanasirm, K. Feeding and lying behavior of heat-stressed early lactation cows fed low fiber diets containing roughage and nonforage fiber sources. J. Dairy Sci. 2015, 98, 1110-1118. [CrossRef] [PubMed]

30. Schulze, A.K.; Weisbjerg, M.R.; Norgaard, P. Effects of feeding level and NDF content of grass-clover silages on chewing activity, fecal particle size and NDF digestibility in dairy heifers. Animal 2014, 8, 1945-1954. [CrossRef] [PubMed]

31. Xu, H.; Hall, M.B.; Gallo-Meagher, M.; Smith, R.L. Improvement of forage quality by downregulation of maize o-methyltransferase. Crop. Sci. 2003, 43, 2240-2251. [CrossRef]

32. Kung, L., Jr.; Shaver, R.D.; Grant, R.J.; Schmidt, R.J. Silage review: Interpretation of chemical, microbial, and organoleptic components of silages. J. Dairy Sci. 2018, 101, 4020-4033. [CrossRef] [PubMed]

33. Muck, R.E.; Nadeau, E.M.G.; McAllister, T.A.; Contreras-Govea, F.E.; Santos, M.C.; Kung, L., Jr. Silage review: Recent advances and future uses of silage additives. J. Dairy Sci. 2018, 101, 3980-4000. [CrossRef]

34. Tang, W.; Wu, X.; Huang, C.; Huang, C.; Lai, C.; Yong, Q. Enhancing enzymatic digestibility of waste wheat straw by presoaking to reduce the ash-influencing effect on autohydrolysis. Biotechnol. Biofuels 2019, 12, 222. [CrossRef]

35. Dong, X.; Zhou, Z.; Saremi, B.; Helmbrecht, A.; Wang, Z.; Loor, J.J. Varying the ratio of Lys:Met while maintaining the ratios of Thr:Phe, Lys:Thr, Lys:His, and Lys:Val alters mammary cellular metabolites, mammalian target of rapamycin signaling, and gene transcription. J. Dairy Sci. 2018, 101, 1708-1718. [CrossRef] [PubMed] 
36. Osorio, J.S.; Ji, P.; Drackley, J.K.; Luchini, D.; Loor, J.J. Supplemental smartamine M or metaSmart during the transition period benefits postpartal cow performance and blood neutrophil function. J. Dairy Sci. 2013, 96, 6248-6263. [CrossRef] [PubMed]

37. Giallongo, F.; Hristov, A.N.; Oh, J.; Frederick, T.; Weeks, H.; Werner, J.; Lapierre, H.; Patton, R.A.; Gehman, A.; Parys, C. Effects of slow-release urea and rumen-protected methionine and histidine on performance of dairy cows. J. Dairy Sci. 2015, 98, 3292-3308. [CrossRef]

38. Lee, C.; Hristov, A.N.; Cassidy, T.W.; Heyler, K.S.; Lapierre, H.; Varga, G.A.; de Veth, M.J.; Patton, R.A.; Parys, C. Rumen-protected lysine, methionine, and histidine increase milk protein yield in dairy cows fed a metabolizable protein-deficient diet. J. Dairy Sci. 2012, 95, 6042-6056. [CrossRef]

39. Giallongo, F.; Harper, M.T.; Oh, J.; Lopes, J.C.; Lapierre, H.; Patton, R.A.; Parys, C.; Shinzato, I.; Hristov, A.N. Effects of rumen-protected methionine, lysine, and histidine on lactation performance of dairy cows. J. Dairy Sci. 2016, 99, 4437-4452. [CrossRef]

40. Van Amburgh, M.E.; Collao-Saenz, E.A.; Higgs, R.J.; Ross, D.A.; Recktenwald, E.B.; Raffrenato, E.; Chase, L.E.; Overton, T.R.; Mills, J.K.; Foskolos, A. The Cornell Net Carbohydrate and Protein System: Updates to the model and evaluation of version 6.5. J. Dairy Sci. 2015, 98, 6361-6380. [CrossRef]

41. Fleming, A.J.; Lapierre, H.; White, R.R.; Tran, H.; Kononoff, P.J.; Martineau, R.; Weiss, W.P.; Hanigan, M.D. Predictions of ruminal outflow of essential amino acids in dairy cattle. J. Dairy Sci. 2019, 102, 10947-10963. [CrossRef]

42. Silva, V.P.; Pereira, O.G.; Leandro, E.S.; da Silva, T.C.; Ribeiro, K.G.; Mantovani, H.C.; Santos, S.A. Effects of lactic acid bacteria with bacteriocinogenic potential on the fermentation profile and chemical composition of alfalfa silage in tropical conditions. J. Dairy Sci. 2016, 99, 1895-1902. [CrossRef] [PubMed]

43. Winters, A.L.; Cockburn, J.E.; Dhanoa, M.S.; Merry, R.J. Effects of lactic acid bacteria in inoculants on changes in amino acid composition during ensilage of sterile and non-sterile ryegrass. J. Appl. Microbiol. 2000, 89, 442-451. [CrossRef] [PubMed]

44. Mahanna, B. Proper management assures high-quality silage, grains. Feedstuffs 1994, 66, 17-20.

45. Li, Q.; Xue, B.; Zhao, Y.; Wu, T.; Liu, H.; Yi, X.; Sun, C.; Wang, Z.; Zou, H.; Yan, T. In situ degradation kinetics of 6 roughages and the intestinal digestibility of the rumen undegradable protein. J. Anim. Sci. 2018, 96, 4835-4844. [CrossRef]

46. Krizsan, S.J.; Nyholm, L.; Nousiainen, J.; Südekum, K.-H.; Huhtanen, P. Comparison of in vitro and in situ methods in evaluation of forage digestibility in ruminants1. J. Anim. Sci. 2012, 90, 3162-3173. [CrossRef]

47. Hao, Y.; Huang, S.; Si, J.; Zhang, J.; Gaowa, N.; Sun, X.; Lv, J.; Liu, G.; He, Y.; Wang, W.; et al. Effects of paper mulberry silage on the milk production, apparent digestibility, antioxidant capacity, and fecal bacteria composition in Holstein dairy cows. Animals 2020, 10, 1152. [CrossRef]

48. Getachew, G.; Robinson, P.H.; DePeters, E.J.; Taylor, S.J. Relationships between chemical composition, dry matter degradation and in vitro gas production of several ruminant feeds. Anim. Feed Sci. Technol. 2004, 111, 57-71. [CrossRef]

49. Kamalak, A.; Canbolat, O.; Gurbuz, Y.; Ozay, O. Comparison of in vitro gas production technique with in situ nylon bag technique to estimate dry matter degradation. Czech. J. Anim. Sci. 2011, 50, 60-67. [CrossRef]

50. Grant, R.J. Influence of corn and sorghum starch on the in vitro kinetics of forage fiber digestion. J. Dairy Sci. 1994, 77, 1563-1569. [CrossRef]

51. Hess, H.D.; Monsalve, L.M.; Lascano, C.E.; Carulla, J.E.; Díaz, T.E.; Kreuzer, M. Supplementation of a tropical grass diet with forage legumes and Sapindus saponaria fruits: Effects on in vitro ruminal nitrogen turnover and methanogenesis. Aust. J. Agric. Res. 2003, 54, 703-713. [CrossRef]

52. Jaworski, N.W.; Lrke, H.N.; Bach Knudsen, K.E.; Stein, H.H. Carbohydrate composition and in vitro digestibility of dry matter and nonstarch polysaccharides in corn, sorghum, and wheat and coproducts from these grains. J. Anim. Sci. 2015, 93, 1103-1113. [CrossRef] [PubMed]

53. Xu, M.; Rinker, M.; McLeod, K.R.; Harmon, D.L. Yucca schidigera extract decreases in vitro methane production in a variety of forages and diets. Anim. Feed Sci. Technol. 2010, 159, 18-26. [CrossRef]

54. Getachew, G.; Laca, E.A.; Putnam, D.H.; Witte, D.; McCaslin, M.; Ortega, K.P.; DePeters, E.J. The impact of lignin downregulation on alfalfa yield, chemical composition, and in vitro gas production. J. Sci. Food Agric. 2018, 98, 4205-4215. [CrossRef]

55. Beuvink, J.M.W.; Spoelstra, S.F. Interactions between substrate, fermentation end-products, buffering systems and gas production upon fermentation of different carbohydrates by mixed rumen microorganisms in vitro. Appl. Microbiol. Biotechnol. 1992, 37, 505-509. [CrossRef]

56. Getachew, G.; Makkar, H.; Becker, K. Tropical browses: Contents of phenolic compounds, in vitro gas production and stoichiometric relationship between short chain fatty acid and in vitro gas production. J. Agric. Sci. 2002, 139, 341-352. [CrossRef] 